\title{
RANCANG BANGUN PEREKAM DATA KELEMBABAN RELATIF DAN SUHU UDARA BERBASIS MIKROKONTROLER
}

\section{(RELATIVE HUMIDITY AND AIR TEMPERATURE MICROCONTROLER- BASED DATA LOGGER DEVELOPMENT)}

\author{
Acta Withamana ${ }^{1}$, Indra Jaya ${ }^{2}$, Ayi Rachmat ${ }^{2}$
}

\begin{abstract}
Relative humidity $(\mathrm{RH})$ and air temperature are important parameter in meteorological measurement. These two parameters should be measured continuously for fisheries and marine environmental monitoring. A data logger for this purpose need to be developed. The data logger consist of ATmega32 microcontroller run at 8Mbz, clock, DS1307 Real-time Clock, Sensirion SHT11 sensor, SD card socket, Low-dropout Linear Regulator LP2950 and AIC1734. Light emitting diode and several passive components such as resistor and capacitor also needed. Data logger firmware was written in BASIC language using BASCOM-AVR version 1.11.9.0. The field test showed the greatest error in measure $\mathrm{RH}$ is $-20,4 \%$ and air temperature is $7,3^{\circ} \mathrm{C}$. Measurement error is caused by contamination in sensor probe and lack of PCB design in releasing beat.
\end{abstract}

Keywords: data logger, relative humidity, air temperature, microcontroller.

\begin{abstract}
ABSTRAK
Kelembaban relatif $(\mathrm{RH})$ dan suhu udara merupakan salah satu parameter yang penting dalam pengukuran meteorologi. Pengukuran kedua parameter secara kontinyu diperlukan dalam bidang perikanan dan kelautan. Sebuah perekam data untuk keperluan ini perlu dikembangkan. Perekam data disusun atas mikrokontroler ATmega32 dengan clock 8Mhz, Real-time clock (RTC) DS1307, Sensor kelembaban relatif dan suhu udara Sensirion SHT11, soket SD card, Low-dropout (LDO) Linear Regulator LP2950 dan AIC1734. Selain itu dibutuhkan LED dan beberapa komponen pasif seperti resistor serta kapasitor. Perangkat lunak atau biasa disebut firmware pada alat perekam data ini ditulis dengan menggunakan bahasa BASIC. Program yang digunakan adalah BASCOM-AVR versi 1.11.9.0. Hasil uji coba skala lapangan menunjukan selisih terbesar $\mathrm{RH}$ sebesar $-20,4 \%$ dan suhu udara sebesar $7,3^{\circ} \mathrm{C}$ yang disebabkan oleh masuknya kontaminan dan desain PCB dan casing yang tidak melepas panas dengan baik.
\end{abstract}

Kata kunci : perekam data, kelembaban relatif, suhu udara dan mikrokontroler.

\section{Pendahuluan}

\subsection{Latar Belakang}

Kelembaban relatif (RH) dan suhu udara merupakan salah satu parameter yang penting dalam pengukuran meteorologi. Pengukuran kelembaban relatif (RH) secara kontinyu dan kemudahan dalam perawatan diperlukan dalam bidang perikanan dan kelautan, antara lain: perekam data RH lingkungan pantai dan lepas pantai secara in situ, manajemen cold storage untuk hasil perikanan tangkap, pengukuran dalam Hazard Analysis Critical Control Point (HACCP), analisis penyimpanan dalam kontainer, dan sebagainya. Kelembaban relatif adalah rasio yang digambarkan sebagai persentase antara tekanan uap air aktual $e$ terhadap tekanan uap jenuh $e_{s}$, pada suhu udara $T$ tertentu (Brock dan Scott, 2001) sedangkan suhu udara adalah jumlah panas yang terkandung di udara (Ritter, 2007).

Pengembangan instrumentasi digital semakin canggih dari waktu ke waktu, seperti halnya pada pengembangan sensor berbasis semikonduktor yang terkalibrasi, memiliki akurasi tinggi dan semakin mudah didapat. Oleh karena itu pengembangan sebuah instrumen yang dapat mengukur kelembaban relatif yang disertai perekam data (data logger) kedalam media penyimpanan secara digital, sudah bisa dilakukan.

\footnotetext{
${ }^{1}$ Sarjana Perikanan Fakultas Perikanan dan Ilmu Kelautan, IPB

${ }^{2}$ Staf Pengajar Fakultas Perikanan dan Ilmu Kelautan IPB
} 


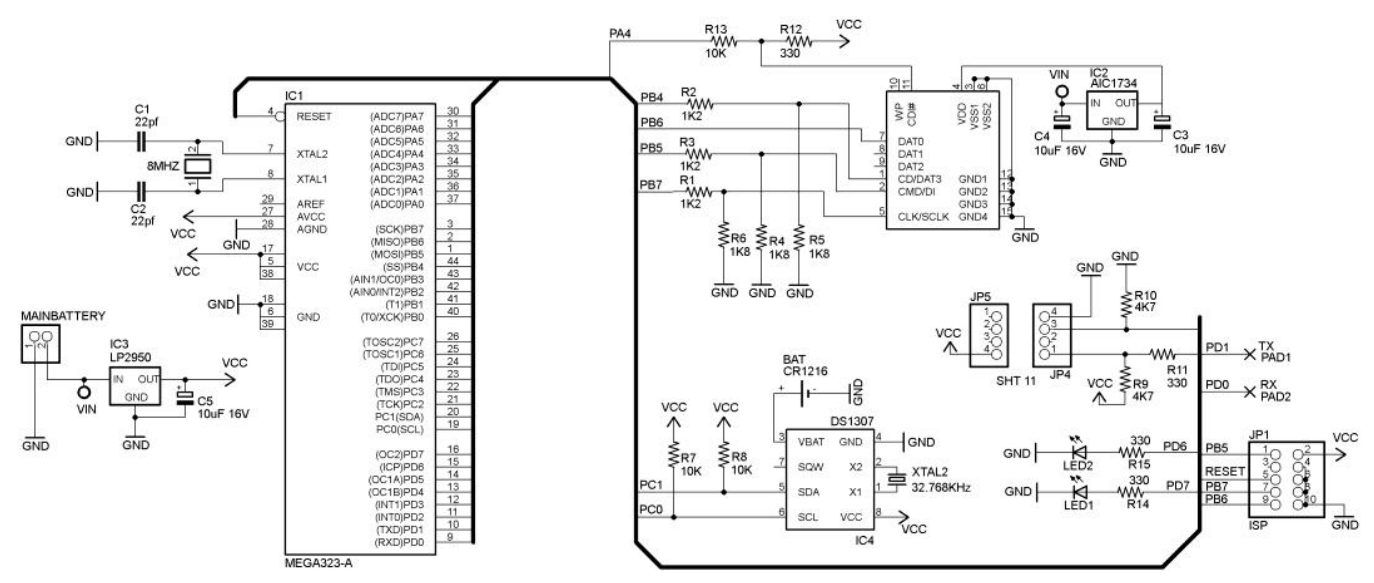

Gambar 1. Skematik lengkap perekam data kelembaban relatif dan suhu udara

\subsection{Tujuan}

Penelitian ini bertujuan untuk membuat instrumen perekam data digital kelembaban relatif dan suhu udara di atas permukaan air laut yang akurat serta memiliki kompatibilitas antar platform yang baik.

\section{METODOLOGI}

Penelitian dimulai pada bulan Juli 2008 dan berakhir bulan November 2008 di Laboratorium Akustik dan Instrumentasi Kelautan, Departemen Ilmu dan Teknologi Kelautan, Fakultas Perikanan dan Ilmu Kelautan, Institut Pertanian Bogor. Terdapat 2 tahap pembuatan instrumen perekam data, yaitu perancangan instrumen dan uji coba alat. Perancangan instrumen meliputi pembuatan perangkat keras dan perangkat lunak (firmware). Desain pembuatan papan PCB perangkat keras menggunakan software EAGLE 5.12 dan membuat firmware menggunakan BASCOM-AVR 1.11.9.0. Sedangkan uji coba yang dilakukan meliputi uji coba skala laboratorium dan uji coba skala lapangan. Uji coba skala laboratorium dilakukan untuk mengetahui kinerja alat perekam data selama minimal $7 \times 24$ jam, sedangkan uji coba skala lapangan dilakukan di Stasiun Klimatologi Dramaga Badan Meteorologi dan Geofisika (BMG), untuk membandingkan hasil pengukuran alat perekam data dengan data BMG selama minimal $7 \times 24$ jam. Lalu hasil yang didapat diolah menggunakan perangkat lunak Microsoft Excel 2007 dan MATLAB R2008b.

\section{HASIL DAN PEMBAHASAN}

\subsection{Perangkat keras}

Perekam data disusun atas Mikrokontroler Atmega32 dengan clock 8Mhz, Real-time Clock (RTC) DS1307,
Sensor kelembaban relatif dan suhu udara Sensirion SHT11, soket SDcard, Lowdropout (LDO) Linear Regulator LP2950 dan AIC1734. Selain itu dibutuhkan LED dan beberapa komponen pasif seperti resistor, serta kapasitor (Gambar 1)

Catu utama menggunakan baterai alkaline sebanyak 4 buah yang dirangkai seri. Baterai ini menghasilkan tegangan 6 volt yang kemudian diregulasi menjadi 5 volt dan 3,3 volt. Tegangan 5 volt digunakan untuk Atmega32, SHT11, dan DS1307, sedangkan 3,3 volt diperlukan oleh SDcard.

Komponen terlindungi oleh pelindung bahan plastik. (Gambar 2).

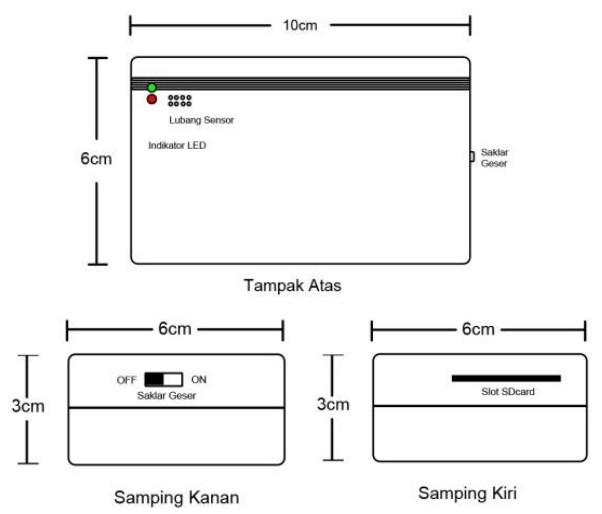

Gambar 2. Dimensi pelindung perekam data suhu udara dan kelembaban relatif

\subsection{Perangkat lunak}

Perangkat lunak atau biasa disebut firmware pada alat perekam data ini ditulis dengan menggunakan bahasa BASIC. Program yang digunakan adalah BASCOM AVR versi 1.11.9.0. Berikut adalah diagram alir perekam data ini. 


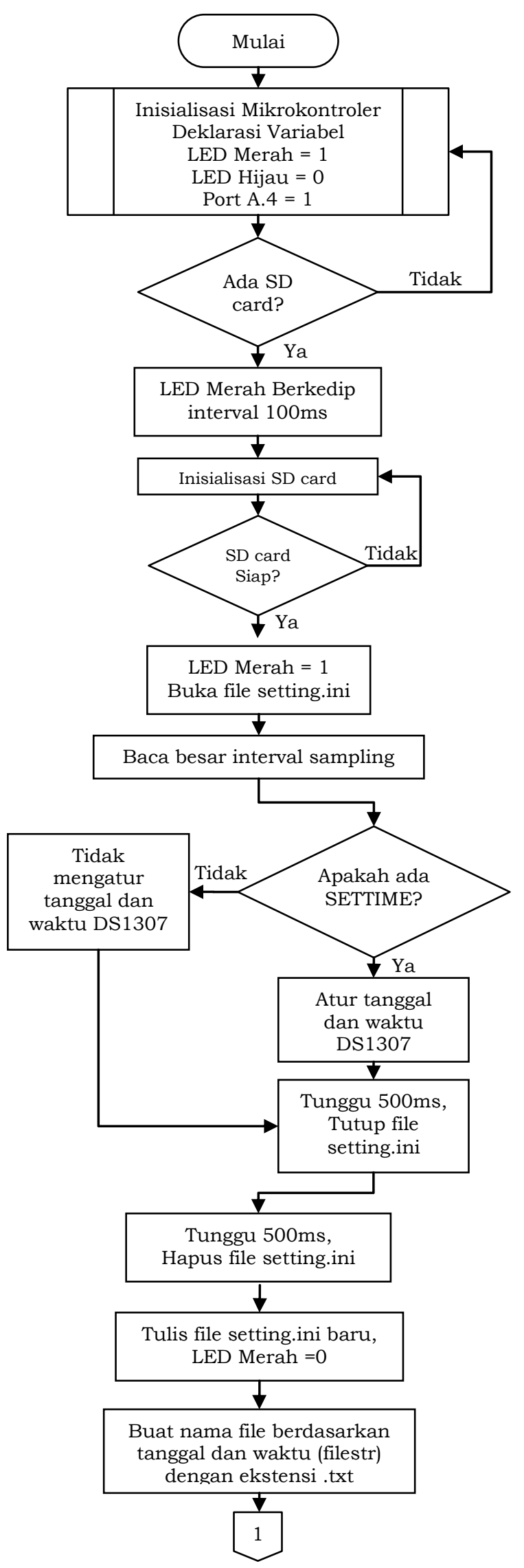

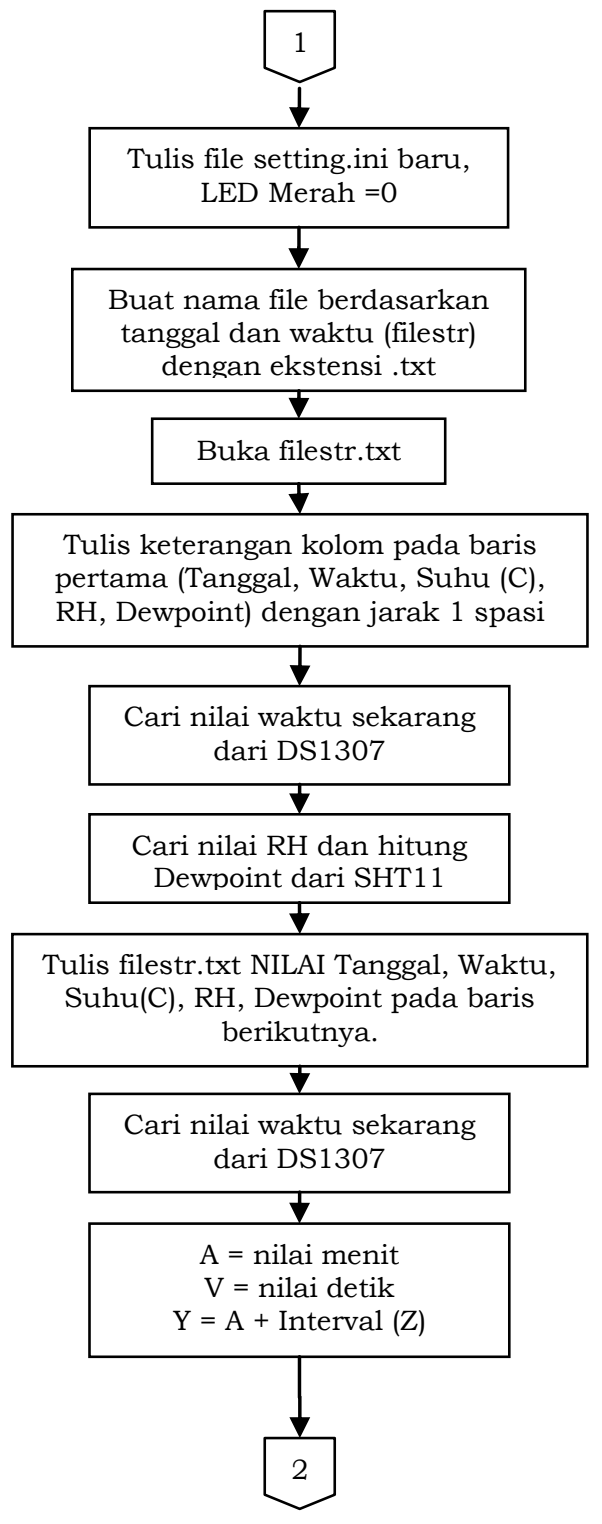




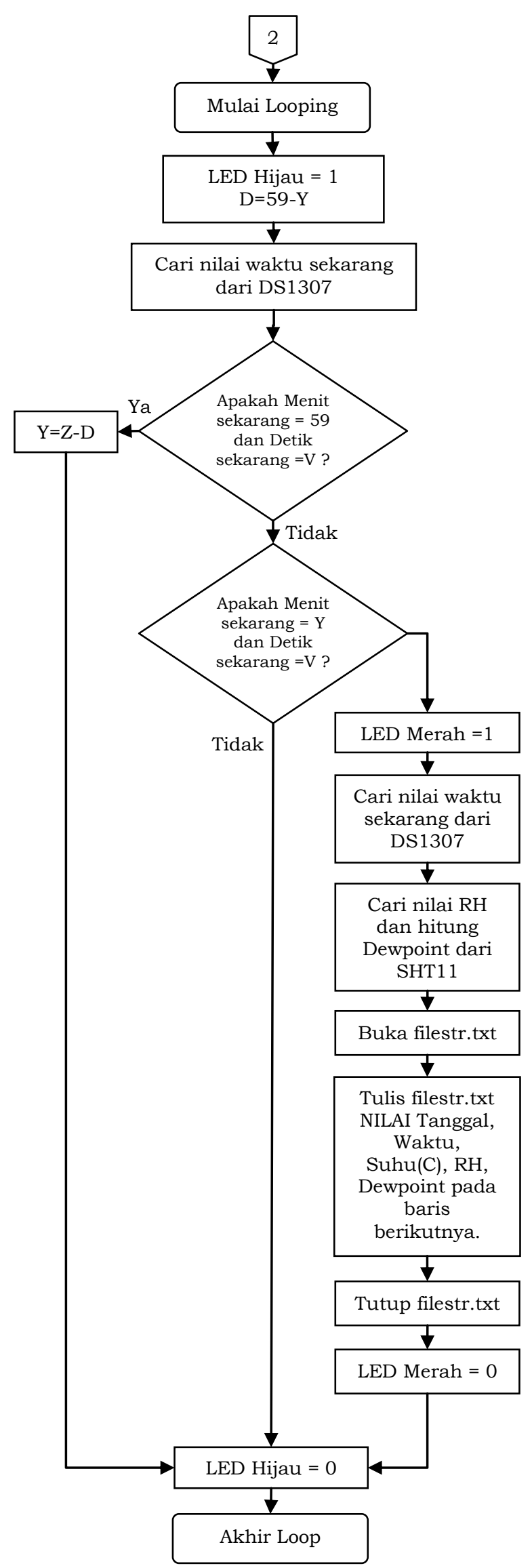

\subsection{Hasil uji coba skala laboratorium}

Uji coba skala laboratorium dilakukan di Laboratorium Akustik dan Instrumentasi Kelautan, Departemen Ilmu dan Teknologi Kelautan, Institut Pertanian Bogor. Dari hasil percobaan (Gambar 3) alat perekam data ini bisa merekam selama kurang lebih 45 jam sampai baterai habis digunakan.

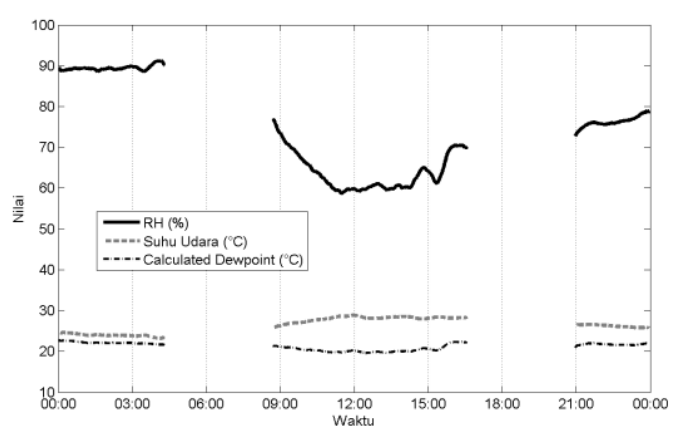

(a)

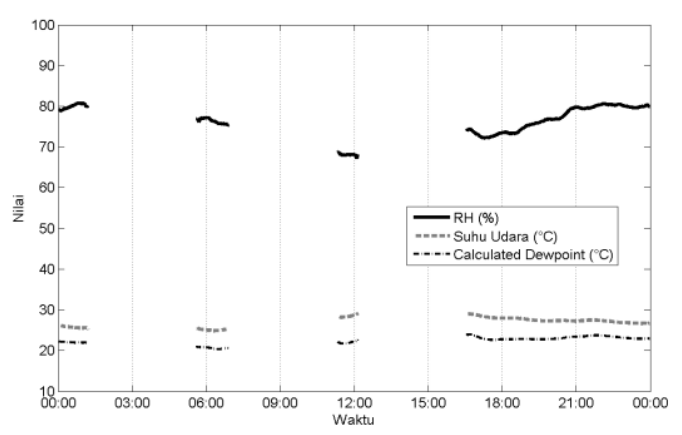

(b)

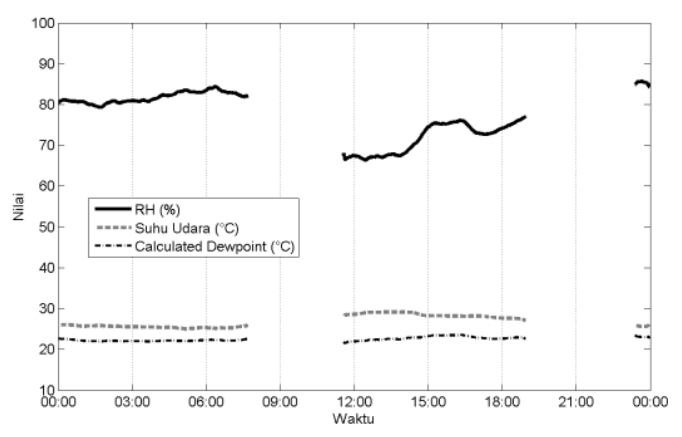

(c)

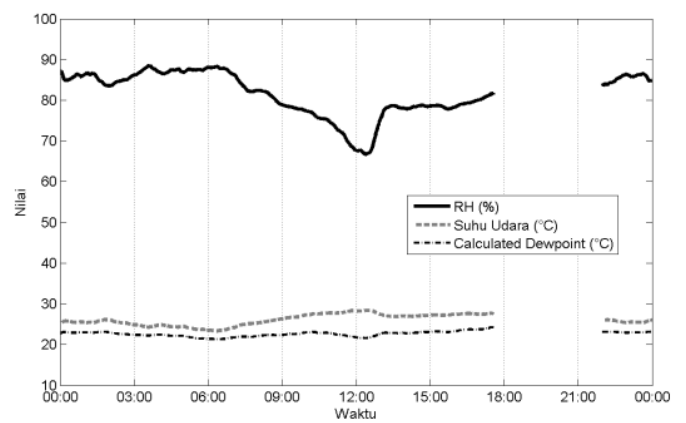

(d) 


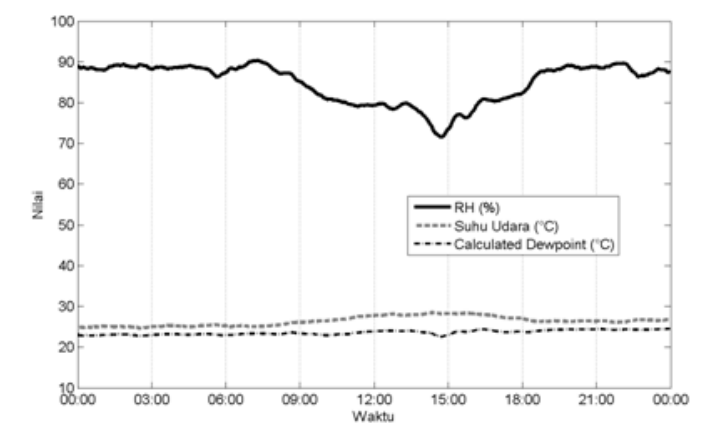

(e)

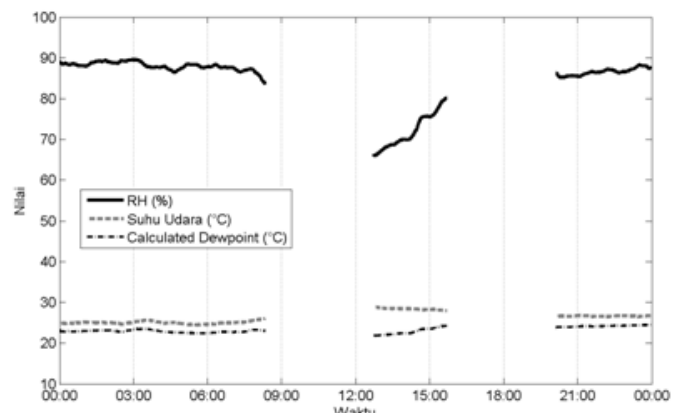

(f)

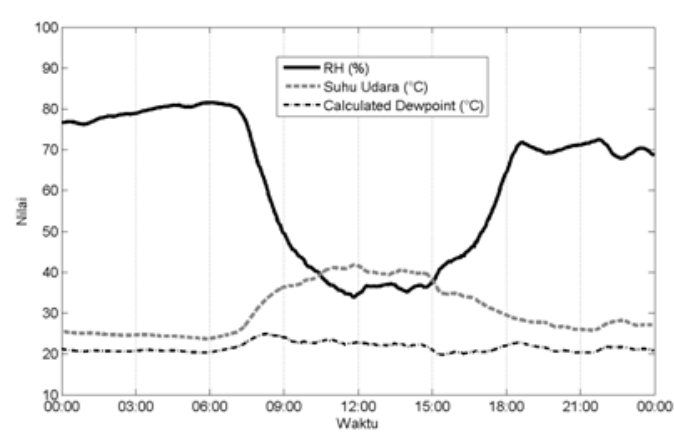

(g)

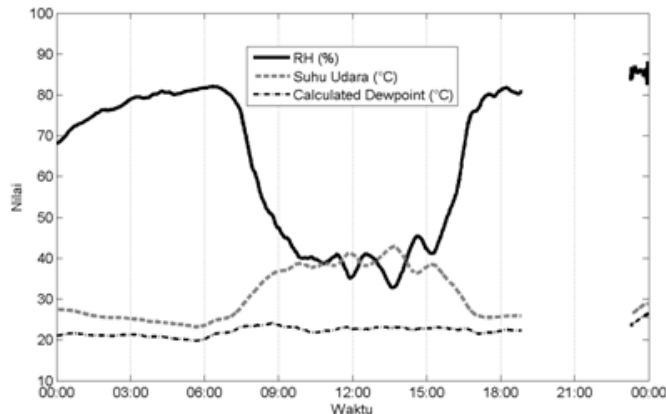

(h)

Gambar 3. Hasil uji coba skala laboratorium tanggal : (a) 6 September 2008, (b) 7 September 2008, (c) 8 September 2008, (d) 9 September 2008, (e) 11 September 2008, (f) 12 September 2008, (g) 27 September 2008, (h) 28 September 2008

Dari Gambar 3 terlihat bahwa alat perekam data kelembaban relatif dan suhu udara berbasis mikrokontroler masih memiliki banyak kekurangan. Terputusnya perekaman data dimungkinkan terjadi karena adanya gangguan pada komunikasi DS1307, ganguan komunikasi dengan SDcard, kurangnya arus untuk menyuplai SDcard, keterbatasan kemampuan mikrokontroler dalam manajemen memori (SRAM), serta kesalahan algoritma pemrograman pada firmware.

\subsection{Hasil uji coba skala lapangan}

Uji coba skala lapangan dilakukan di Stasiun Lapang Klimatologi Darmaga Badan Meteorologi dan Geofisika. Alat perekam data diletakan dalam sangkar berdampingan dengan termometer bola basah dan termometer bola kering. Interval pengambilan data sebesar 1 menit, sedangkan data pembanding BMG diambil dengan interval 1 jam.

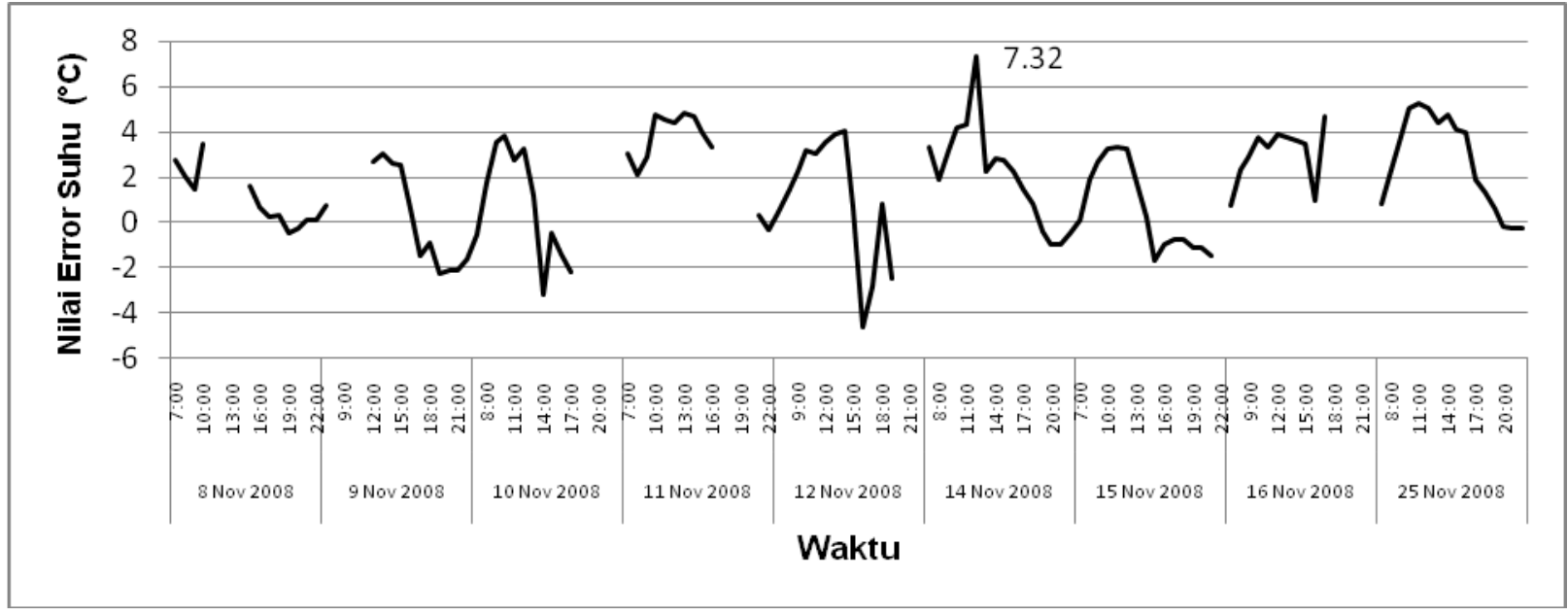

Gambar 4. Grafik error suhu udara pada pengujian skala lapangan 


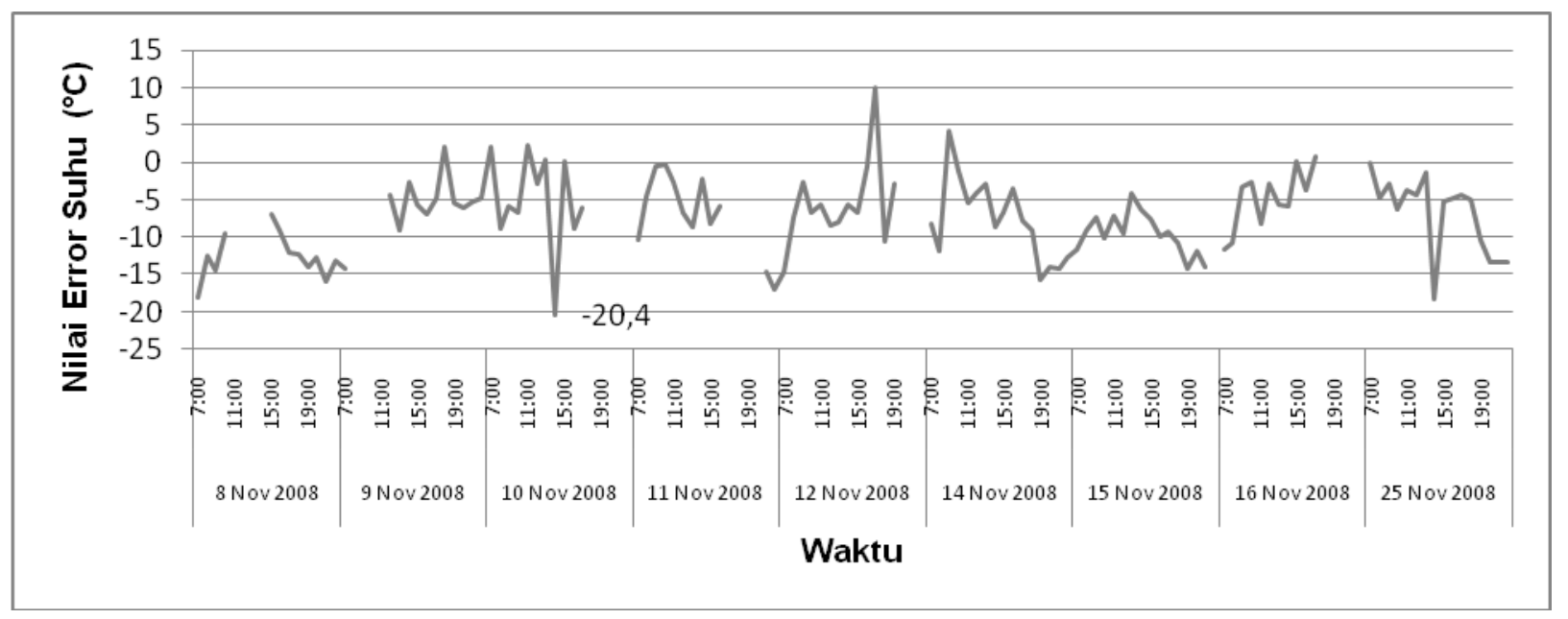

Gambar 5. Grafik error RH pada pengujian skala lapangan

Gambar 4 dan Gambar 5 menunjukkan terdapat selisih yang besar antara data hasil rekaman dengan data BMG. Nilai minus (-) menunjukan bahwa nilai data rekaman lebih kecil dibandingkan data BMG. Sebaliknya, nilai (+) menunjukan bahwa nilai data rekaman lebih besar daripada nilai BMG. Selisih terbesar RH dari semua hari pengamatan adalah sebesar $-20,4 \%$, sedangkan selisih suhu udara terbesar sebesar $7,3^{\circ} \mathrm{C}$.

\section{KESIMPULAN}

Instrumen perekam data kelembaban relatif dan suhu udara berbasis mikrokontroler telah dikembangkan dalam penelitian ini, namun masih perlu disempurnakan. Walaupun fungsinya sebagai perekam data sudah bisa dibuktikan, namun terdapat beberapa masalah yang perlu diatasi.

Data perekaman yang terputus salah satu masalah yang perlu dipecahkan. Faktor-faktor penyebab tidak terekamnya data antara lain : komunikasi mikrokontroler dengan DS1307 terganggu, komunikasi mikrokontroler dengan SD card terganggu, keterbatasan mikrokontroler dalam manejemen memori.

Selisih antara nilai hasil perekaman juga termasuk besar. Selisih terbesar $\mathrm{RH}$ dari semua hari pengamatan adalah sebesar $-20,4 \%$, sedangkan selisih suhu udara terbesar sebesar $7,3^{\circ} \mathrm{C}$. Faktor-faktor yang mungkin menyebabkannya adalah kesalahan pengukuran sensor suhu udara dan kelembaban relatif SHT11 akibat masuknya kontaminan, serta desain PCB dan casing yang tidak bisa melepas panas dengan baik sehingga mempengaruhi Sensirion SHT11.

\section{SARAN}

Desain elektronik secara keseluruhan harus ditinjau kembali, terutama bagian catu daya, DS1307 dan SDcard. Perlu dilakukan pengambilan data dari instrumen digital yang telah terkalibrasi dan perlunya pengkalibrasian ulang sensor suhu udara dan kelembaban relatif SHT1, baik secara perangkat keras dengan melakukan pengeringan dan rehidrasi, maupun perangkat lunak. Analisis termal sebaiknya dilakukan agar Sensirion SHT11 tidak terpengaruh oleh radiasi panas komponen lain. Perlunya menggunakan baterai yang bisa diisi ulang, walaupun akan menambah rangkaian secara keseluruhan. Perbaikan antarmuka pengguna (User Interface) berupa manjemen file hasil rekaman yang lebih baik, misal membuat file berdasarkan hari perekaman.

\section{DAFTAR PUSTAKA}

AIC. 2006. AIC1734 300mA Low Dropout Linear Regulator. http://www.analog.com.tw/ImgSho w/DS-1734G-01.pdf. [31 Juli 2008]

Atmel. 2008. 8-bit $A V R^{\circledR}$ Microcontroller with $32 \mathrm{~KB}$ In-System Programmable Flash.

http://www.atmel.com/dyn/resourc es/prod_documents/doc2503.pdf. [31 Juli 2008]

Blundell, S. J., dan K. M. Blundell. 2006. Concept in Thermal Physics. Hal. 30- 
40. Oxford University Press US. New York, NY. 483h.

Brock, F.V., dan S. J. Richardson. 2001. Meteorogical Measurement System. Oxford University Press US. New York, NY. 310 h.

Dallas-Maxim Semiconductor. 2008. DS1307 $64 \times$ 8, Serial, I2C Real-Time Clock. http://datasheets.maximic.com/en/ds/DS1307.pdf. [31 Juli 2008]

Davis, L. 2008. Secure Digital Card Pinout. http://www.interfacebus.com/Secur e_Digital_Card_Pinout.html. [31 Juli 2008]

Fontes, J. 2005. Humidity Sensors. h.271285. In. J.Wilson (ed.). Sensor Technology Handbook. Elsevier. Oxford.

Gadre, D.V. 2001. Programing and Customizing The AVR Microcontroller. McGraw-Hill. New York, NY. 366h.

Kalinsky, D., dan R. Kalinsky. 2002. Introduction to Serial Peripheral Interface.

http://www.embedded.com/story/O EG20020124S0116. [5 Agustus 2008]

Kenny, T. 2005. Sensor Fundamentals. h.120. In. J.Wilson (ed.). Sensor Technology Handbook. Elsevier. Oxford.

Linden, D. 2002. Basic Concept. ch. 1.1-1.5. In Linden,D., dan Thommas B.R.(ed.). Handbook of Batteries. Third Edition. McGraw-Hill. Boston.

National Semiconductor. 2005. LP2950/LP2951. Series of Adjustable Micropower Voltage Regulator.

http://www.national.com/ds/LP/LP 2950.pdf. [31 Juli 2008]

NWS. 2005.2 Dew Point. http://www.weather.gov/glossary/in dex.php?word=dew\%20point. [4 Februari 2009]

Ramdani, T. 2006. Rancang Bangun Prototipe Irradiance-Meter Bawah Air. Skripsi (Tidak Dipublikasikan). Fakultas Perikanan dan Ilmu Kelautan. IPB. Bogor.

Roveti, D. K. 2001. Choosing a Humidity Sensor: A Review of Three
Technologies.

http://www.sensorsmag.com/article

s/0701/54/main.shtml.

Desember 2008]

Sensirion. 2007. SHT1x/SHT7x Humidity and Temperature Sensor. http://www.sensirion.com/images/g etFile?id=25. [31 Juli 2008]

The Engineering ToolBox. 2005. Thermal Conductivity of some common materials.

http://www.engineeringtoolbox.com /thermal-conductivity-d_429.html. [4 Februari 2009]

Park, J.L. 1998. The Meaning of Reduction and Oxidation. http://dbhs.wvusd.k12.ca.us/webdo cs/Redox/Meaning-of-Redox.html. [2 Desember 2008]

Ritter, M. 2007. Air Temperature Patterns. http://www.uwsp.edu/geo/faculty/r itter/geog101/uwsp_lectures/lecture _atmospheric_temperature.html. [14 November 2008]

Scarr F.R., J. C. Hunter, dan P. J. Slezak. 2002. Alkaline-Manganese Dioxide Batteries. ch. 10.1-10.5. In Linden,D.,dan Thommas B.R.(ed.). Handbook of Batteries. Third Edition. McGraw-Hill. Boston.

Webopedia. 2003. What is Microcontroller?. http://www.webopedia.com/TERM/ $\mathrm{m} /$ microcontroller.html [31 Juli 2008]

Yunus, A. 2003. Rancang Bangun Alat Pengukur Suhu dan Salinitas Digital Berbasis Mikrokontroler 89C51. Skripsi (Tidak Dipublikasikan). Fakultas Perikanan dan Ilmu Kelautan. IPB. Bogor.

Zamacona, J. R. D., G. Calva, M. A. B. Saucedo, J. Castillo, dan S. Quintana. 2004. Meteorogical Unit for Didactic Uses (UMUD). Journal of Applied Research and Technology. 2(003): 255-260

Zumbahlen, M (ed.). 2008. Linear Circuit Design Handbook. Hal 684-700. Elsevier. Amsterdam. 943h. 